\title{
ANALISIS ALTMAN Z-SCORE, GROVER SCORE, SPRINGATE, DAN ZMIJEWSKI SEBAGAI SIGNALING FINANCIAL DISTRESS (Studi Empiris Industri Barang-Barang Konsumsi di Indonesia)
}

\author{
Niken Savitri Primasari \\ Fakultas Ekonomi dan Bisnis, Universitas Nahdlatul Ulama Surabaya \\ e-mail: nikensp.hendrawan@outlook.co.id
}

\begin{abstract}
This study purpose to determine whether there are differences among Altman model, Springate model and Zmijewski model to predict financial distress, and to find out which the Financial Distress prediction model has the most excellent implementation in Indonesia manufacture industry. Comparison of those six models were made by analyzing the accuracy of each model, by using the real condition of a company's net income. The data used in the form of annual financial statements published by the company on the Indonesia Stock Exchange website.
\end{abstract}

The sample in this study consisted of 116 financial data from 29 companies in Consumer Goods Industry. All companies are listed in Indonesia Stock Exchange Market at period 2012 - 2015. The company does not conclude yet, whether there is a prediction model that best suit the measurement. This cause by: (1) every model have its own superiority and weakness, (2) the company sample characteristic differences (company sector, company size) also influence the choice of prediction model being used, (3) the company financial ratio as independent variable used in bankruptcy prediction.

Since the financial statements are reflecting the company's financial ability of the signaling, the researchers limited the industry with the highest value of EPS and PER. This is done to avoid confounders in the proof of the accuracy of the model, Springate model, Oblson model and Zmijewski model to predict financial distress. The data obtained from the Annual Financial Statements, IDX Fact Book and the Indonesian Capital Market Directory.

In this study will be used $t$ test, additional testing is done to see the feasibility of the model by observing the $F$ test results and test the coefficient of determination (R2), $R 2$ value used to examine differences among Altman, Grover, Springate and Zmijewski models in predicting financial distress. The analytical tool used is the One Way ANOVA with level of significance $5 \%$.

The results from this research showed that any prediction model used in this study can be used to predict Financial Distress, particularly the Altman Z-Scores, which have the greater R2 analysis. Only Grover G-Score models have insignificant value t test and F-test is greater than the probability cannot be used to predict corporate Financial Distress.

The results also showed that the most accurate model is the model Altman Z-Score. At the end of the study was to try predict 29 firms sample used listed on the Stock Exchange with Altman model. Predicted results showed that five companies are expected to experience Financial Distress in the future.

Keywords: financial distress, prediction models, financial ratio, financial statement

\section{A. PENDAHULUAN}

\section{Latar Belakang}

Laporan keuangan digunakan sebagai bentuk pertanggungjawaban kepada publik untuk memonitor kinerja dan mengevaluasi manajemen, memberikan dasar untuk mengamati tren antar-kurun waktu, pencapaian atas tujuan yang telah ditetapkan dan membandingkannya dengan kinerja organisasi lain yang sejenis jika ada, 
serta memungkinkan pihak luar untuk memperoleh informasi biaya atas barang dan jasa yang diterima dan untuk menilai efisiensi dan efektivitas penggunaan sumber daya organisasi. Laporan keuangan juga berfungsi untuk membantu perusahaan untuk memberikan dasar perencanaan kebijakan dan aktivitas di masa yang akan datang, terutama informasi pendukung penggunaan dana dan kelangsungan organisasi (viability).

Setiap perusahaan didirikan dengan harapan akan menghasilkan profit sehingga mampu untuk bertahan dan berkembang dalam jangka panjang yang tak terbatas. Hal ini berarti dapat diasumsikan bahwa perusahaan akan terus hidup dan diharapkan tidak akan mengalami likuidasi. Dalam praktik, asumsi seperti di atas tidak selalu menjadi kenyataan. Seringkali perusahaan yang telah beroperasi dalam jangka waktu tertentu terpaksa bubar karena mengalami financial distress yang berujung pada kebangkrutan (Rismawaty, 2012).

Signaling theory menunjukkan adanya asimetri informasi yang bias terlihat dari bentuk pelaporan keuangan perusahaan kepada pengguna laporan keuangan, baik untuk internal manajemen perusahaan itu sendiri sebagai bentuk kebutuhan pada planning, actuating dan controlling keuangan, maupun untuk pihak-pihak luar yang berkepentingan dengan informasi tersebut.

Menurut Maria Immaculatta (2006), kualitas keputusan investor dipengaruhi oleh kualitas informasi yang diungkapkan perusahaan dalam laporan keuangan. Kualitas informasi tersebut bertujuan untuk mengurangi asimetri informasi yang timbul ketika manajer lebih mengetahui informasi internal dan prospek perusahaan di masa mendatang dibanding pihak eksternal perusahaan. Informasi yang berupa pemberian pemeringkatan yang dipublikasikan terhadap perusahaan yang tercatat diharapkan dapat menjadi sinyal kondisi keuangan perusahaan tertentu dan menggambarkan kemungkinan yang terjadi terkait dengan kinerja dan utang yang dimiliki oleh perusahaan tersebut.

Menurut Kusuma (2006) pada signaling theory terdapat motivasi manajemen dalam menyajikan informasi keuangan yang diharapkan dapat memberikan sinyal kemakmuran kepada pemilik ataupun pemegang saham. Publikasi laporan keuangan tahunan yang disajikan oleh perusahaan akan dapat memberikan signal pertumbuhan dividen maupun perkembangan harga saham perusahaan.

Sehingga dapat dikatakan bahwa Publikasi laporan keuangan tahunan dan publikasi data perusahaan yang dikeluarkan oleh BEI (Bursa Efek Indonesia) baik berupa rating industri maupun hasil pengolahan rasio oleh pihak BEI, dapat menunjukkan kondisi keuangan baik secara industri ataupun masing-masing perusahaan terbuka. Informasi BEI tersebut diharapkan akan mampu memberikan sinyal bagi investor maupun calon investor mengenai kinerja perusahaan tertentu.

Perusahaan manufaktur merupakan industri yang dalam kegiatannya mengandalkan modal dari investor, oleh karena itu perusahaan manufaktur harus dapat menjaga kestabilan keuangannya. Mengingat besarnya pengaruh yang timbul bila terjadi kesulitan keuangan pada industri manufaktur, maka perlu dilakukan analisis sedemikian rupa sehingga kesulitan keuangan dan kemungkinan kebangkrutan dapat dideteksi lebih awal.

Berbagai pengembangan analisis keuangan tersebut dilakukan untuk memprediksi kondisi keuangan perusahaan. Analisis yang banyak digunakan saat ini adalah analisis diskriminan altman, 
di mana analisis ini mengacu pada rasio-rasio keuangan perusahaan. Rasio menggambarkan suatu hubungan atau pertimbangan (mathematical relationship) antara suatu jumlah tertentu dengan jumlah yang lain, dan dengan menggunakan alat analisis berupa rasio ini akan dapat menjelaskan atau memberi gambaran kepada penganalisis tentang baik atau buruknya keadaan atau posisi keuangan suatu perusahaan terutama apabila angka ratio pembanding yang digunakan sebagai standar (Munawir, 2007:64).

Selain analisis diskriminan altman, masih banyak jenis model yang telah digunakan penelitipeneliti sebelumnya dalam memprediksi keadaan keuangan suatu perusahaan. Misalnya saja, model springate, model zmijewski, model ohlson, model fulmer, model CA-score, dan sebagainya.

Dengan diketahui model-model prediksi kondisi keuangan yang tepat dan penggunaan informasi keuangan perusahaan-perusahaan terpublikasi oleh BEI, diharapkan investor maupun pihak-pihak lain yang berkepentingan dalam analisis keuangan agar dapat mengambil keputusan dengan lebih baik.

Penelitian ini dilakukan di perusahaan sektor industri barang konsumsi yang terdaftar di Bursa Efek Indonesia yang merupakan salah satu industri manufaktur yang mempunyai peran aktif dalam pasar modal. Industri barang konsumsi memiliki 5 sub sektor industri dengan total jumlah perusahaan tercatat 34 di akhir tahun 2011 dan kini, bertambah menjadi 36 di akhir tahun 2016, namun tercatat hanya 1 perusahaan saja yang melakukan dividend payment di setiap tahunnya. Padahal salah satu kriteria perusahaan dapat dikatakan memiliki financial distress, yakni saat perusahaan tersebut lebih dari satu tahun tidak melakukan pembagian (pembayaran) dividen.

\section{Perumusan Masalah}

Berdasarkan uraian latar belakang di atas dapat dirumuskan permasalahan penelitian sebagai berikut.

1. Model analisis prediksi kondisi keuangan ( $f i-$ nancial distress) manakah yang paling akurat dalam memprediksi kondisi keuangan perusahaan di sektor industri barang konsumsi Indonesia?

2. Berdasarkan model prediksi yang paling akurat tersebut, perusahaan pada apa sajakah pada sektor industri barang konsumsi Indonesia yang diprediksi tidak mengalami kondisi financial distress?

3. Sebaliknya, perusahaan pada sektor industri barang konsumsi Indonesia apa sajakah yang diprediksi memiliki prediksi kondisi keuangan perusahaan yang buruk?

\section{Tujuan Penelitian}

1. Mengetahui model prediksi mana yang paling akurat dalam memprediksi financial distress perusahaan sektor industri barang konsumsi Indonesia.

2. Mengetahui perusahaan sektor industri barang konsumsi Indonesia yang diprediksi tidak mengalami kondisi financial distress.

3. Mengetahui perusahaan sektor industri barang konsumsi Indonesia yang diprediksi mengalami kondisi keuangan yang buruk atau mengalami financial distress.

\section{B. TINJAUAN TEORI DAN PENGEMBANG- AN HIPOTESIS}

\section{Laporan Keuangan dan Teori Signaling}

Laporan keuangan yang mencerminkan kinerja baik merupakan signal atau tanda bahwa 
perusahaan telah beroperasi dengan baik. Signal baik akan direspons dengan baik pula oleh pihak luar, karena respons pasar sangat tergantung pada signal fundamental yang dikeluarkan perusahaan. Investor hanya akan menginvestasikan modalnya jika menilai perusahaan mampu memberikan nilai tambah atas modal yang diinvestasikan lebih besar dibandingkan jika menginvestasikan di tempat lain. Untuk itu, perhatian investor diarahkan pada kemampulabaan perusahaan yang tecermin dari laporan keuangan yang diterbitkan perusahaan.

Suad Husnan dan Enny (2002) laporan keuangan yang pokok ada dua sebagai berikut. (1) Neraca adalah suatu sumber informasi dari laporan keuangan yang digunakan untuk menunjukkan kekayaan yang dimiliki perusahaan, yang berupa aktiva, kewajiban, dan ekuitas pada periode tertentu, kekayaan disajikan pada sisi aktiva sedangkan kewajiban dan modal sendiri disajikan pada sisi pasiva. (2) Laporan laba rugi menunjukkan laba atau rugi suatu perusahaan pada periode waktu tertentu.

James dan Moira (2005:2) Laporan keuangan adalah alat atau sarana utama dalam menciptakan laporan informasi keuangan kepada pihak yang berkepentingan seperti pihak internal (manajemen dan para karyawan) dan pihak eksternal (bank, investor, pemerintah). Menurut Ryan dan Miyosi (2013) tujuan laporan keuangan adalah sebagai berikut. (1) Memberikan berbagai macam informasi pada periode tertentu (periode akuntansi/satu tahun) misalnya seperti perubahan asset perusahaan. (2) Memberikan penilaian tentang kondisi perusahaan atau kinerja keuangan perusahaan. (3) Membantu dalam memberikan pertimbangan untuk pihak-pihak tertentu. Setiap perusahaan diharuskan adanya laporan keuangan di mana laporan keuangan ini dapat digunakan untuk mengetahui kinerja dan kondisi keuangan perusahaan yang dapat digunakan untuk mem- prediksi adanya potensi kebangkrutan di masa yang akan datang.

Teori sinyal melandasi penelitian ini dan digunakan untuk menjelaskan bahwa laporan keuangan digunakan untuk memberi sinyal positif (good news) maupun sinyal negatif (bad news) kepada pemakainya. Sumeth Tuvaratragool (2013) melakukan penelitian tentang pengaturan perbandingan rasio keuangan dalam memberi sinyal adanya financial distress dengan menggunakan teknik multi ukur (IMM) yang terdiri dari emerging market, skor model, analisis komparatif rasio, dan analisis tren rasio dan model logit sebagai benchmarking ukuran, hasil penelitian ini menunjukkan bahwa informasi laporan keuangan dapat dijadikan media untuk mengetahui sinyal adanya kegagalan perusahaan atau kebangkrutan.

Setiap pihak yang memiliki hubungan dengan perusahaan sangat berkepentingan dengan kinerja perusahaan. Pentingnya pengukuran kinerja perusahaan dapat dijelaskan dengan dua teori yaitu teori keagenan (agency theory) dan teori pensignalan (signaling theory).

Teori kedua yang menjelaskan pentingnya pengukuran kinerja adalah teori pensignalan (signaling theory). Teori signal membahas bagaimana seharusnya signal-signal keberhasilan atau kegagalan manajemen (agen) disampaikan kepada pemilik (principal). Teori signal menjelaskan bahwa pemberian signal dilakukan oleh manajemen untuk mengurangi informasi asimetris. Menurut Sari dan Zuhrotun (2006), teori signal (signaling theory) menjelaskan mengapa perusahaan mempunyai dorongan untuk memberikan informasi laporan keuangan kepada pihak eksternal, agar perusahaan memiliki hubungan baik dan kredibel di mata investor. Hubungan antara pemilik dan manajemen sangat tergantung pada penilaian pemilik dalam hal ini investor, tentang kinerja manajemen. Untuk itu, pemilik menuntut 
pengembalian atas investasi yang dipercayakan untuk dikelola oleh manajemen.

Hubungan baik akan terus berlanjut jika pemilik ataupun investor puas dengan kinerja manajemen, dan penerima signal juga menafsirkan signal perusahaan sebagai signal yang positif. Hal ini jelas bahwa pengukuran kinerja keuangan perusahaan merupakan hal yang krusial dalam hubungan antara manajemen dengan pemilik ataupun investor. Laporan tentang kinerja perusahaan yang baik akan meningkatkan nilai perusahaan.

Umumnya laporan keuangan sangatlah penting untuk setiap perusahaan baik perusahaan yang telah go public maupun tidak, karena dapat digunakan untuk mengetahui kinerja dan kondisi keuangan perusahaan sehingga dapat memprediksi adanya potensi kebangkrutan di masa yang akan datang.

\section{Kondisi Financial Distress}

Financial distress merupakan kondisi di mana adanya ketidakmampuan perusahaan untuk memenuhi kewajiban lancarnya yang telah jatuh tempo misalnya; utang usaha, utang pajak, utang bank jangka pendek. Brigham and Gapenski (1997) membagi definisi financial distress menjadi beberapa tipe yaitu economic failure, business failure, technical insolvency, insolvency in bankruptcy, dan legal bankruptcy.

Dapat dikatakan bahwa sepanjang perusahaan memiliki arus kas yang lebih besar dari kewajiban utangnya maka perusahaan akan memiliki cukup dana untuk membayar krediturnya. Di sini faktor yang menjadi kunci dalam mengidentifikasi apakah perusahaan berada dalam kondisi financial distress adalah ketidakmampuan perusahaan dalam memenuhi kewajibannya. Financial distress adalah kondisi di mana perusahaan mengalami laba bersih operasi (net operation income) negatif selama beberapa tahun dan selama lebih dari satu tahun tidak melakukan pembayaran dividen, pemberhentian tenaga kerja atau menghilangkan pembayaran dividen (Almilia dan Kristijadi, 2003). Selain definisi di atas, isu lain yang juga penting adalah adanya kesalahan umum yang umumnya menyamakan financial distress dengan kebangkrutan. Padahal, hal ini tidak benar, financial distress hanyalah salah satu penyebab bangkrutnya sebuah perusahaan. Namun tidak berarti semua perusahaan yang mengalami financial distress akan menjadi bangkrut.

Model financial distress perlu dikembangkan, karena diharapkan dapat melakukan tindakan-tindakan untuk mengantisipasi kondisi yang mengarah pada kebangkrutan, seperti mengubah asset menjadi kas atau untuk memenuhi kewajiban keuangan jangka pendek perusahaan, mengalkulasi dana perusahaan yang tertanam dalam aset berputar untuk menghasilkan revenue, menerbitkan saham untuk mendapatkan modal, hingga meminjam modal dari kreditor. Sehingga keadaan terburuk seperti kebangkrutan dapat dihindari perusahaan.

Metode prediksi kebangkrutan adalah model yang digunakan untuk menilai kapan perusahaan akan bangkrut dengan menggabungkan sekelompok rasio keuangan yang nantinya akan memberikan gambaran mengenai kondisi keuangan atau kinerja perusahaan. Salah satu faktor yang menopang perusahaan agar tetap beroperasi adalah faktor finansial atau kondisi keuangan perusahaan, sehingga banyak peneliti yang telah mengembangkan model prediksi kebangkrutan.

\section{Model Prediksi Kesulitan Keuangan}

\section{a. Model Altman}

Altman (1968) menggunakan model stepwise multivariate discriminant analysis (MDA) 
dalam penelitiannya. Seperti regresi logistik, teknik statistika ini juga biasa digunakan untuk membuat model di mana variabel dependennya merupakan variabel kualitatif. Output dari teknik MDA adalah persamaan linear yang bisa membedakan antara dua keadaan variabel dependen.

Kelima rasio yang digunakan altman dimasukkan ke dalam analisis MDA dan menghasilkan model sebagai berikut.

$\mathrm{Z}=1.2 \mathrm{X}_{1}+1.4 \mathrm{X}_{2}+3.3 \mathrm{X}_{3}+0.6 \mathrm{X}_{4}+1.0 \mathrm{X}_{5}$

Di mana:

$\mathrm{X}_{1}=$ working capital/total assets

$\mathrm{X}_{2}=$ retained earning/total assets

$\mathrm{X}_{3}=\mathrm{EBIT} /$ total assets

$\mathrm{X}_{4}=$ Market value of equity/total liabilities

$\mathrm{X}_{5}=$ Sales/total assets

Keterangan:

Working Capital= = Current Assets Current Liabilities

Market Value of Equity $=$ Shares Outstanding $\mathrm{x}$ Current Share Price

Altman menggunakan nilai cut-off 2,675 dan 1,81 . Artinya jika nilai $Z$ yang diperoleh lebih dari 2,675, perusahaan diprediksi tidak mengalami financial distress di masa depan. Perusahaan yang nilai Z-nya berada di antara 1,81 dan 2,675 berarti perusahaan itu berada dalam grey area, yaitu perusahaan mengalami masalah dalam keuangannya.

\section{b. Model G-Score Grover}

Model grover merupakan model yang diciptakan dengan melakukan pendesainan dan penilaian ulang terhadap model altman Z-score. Jeffrey S. Grover menggunakan sampel sesuai dengan model altman Z-score pada tahun 1968 dengan menambahkan 13 rasio keuangan baru. Sampel yang digunakan sebanyak 70 perusahaan dengan 35 perusahaan yang bangkrut dan 35 perusahaan yang tidak bangkrut pada tahun 1982 sampai 1996. Grover (2001) dalam Prihanthini (2013) menghasilkan persamaan sebagai berikut.

$$
\begin{aligned}
\mathrm{G}-\mathrm{S} \text { core }= & 1,650 \mathrm{X} 1+3,404 \mathrm{X} 3-0,016 \mathrm{ROA}+ \\
& 0,057
\end{aligned}
$$

Keterangan:

$\mathrm{X} 1=$ Working capital/total assets

$\mathrm{X} 3=$ Earnings before interest and taxes/total assets

$\mathrm{ROA}=$ net income/total assets

Model Grover mengategorikan perusahaan dalam keadaan bangkrut dengan skor kurang atau sama dengan $-0,02(G \leq-0,02)$ sedangkan nilai untuk perusahaan yang dikategorikan dalam keadaan tidak bangkrut adalah lebih atau sama dengan 0,01 ( $G$ 0,01). Perusahaan dengan skor di antara batas atas dan batas bawah berada pada grey area.

\section{c. Model Springate}

Model ini dikembangkan pada tahun 1978 oleh Gorgon L.V. Springate. Model springate adalah model rasio yang menggunakan multiple discriminate analysis atau MDA untuk memilih 4 rasio dari 19 rasio keuangan yang populer dalam literatur-literatur, yang mampu membedakan secara terbaik antara sound business yang pailit dan tidak pailit. Model springate adalah sebagai berikut.

$\mathrm{S}=1,03 \mathrm{X}_{1}+3,07 \mathrm{X}_{2}+0.66 \mathrm{X}_{3}+0,4 \mathrm{X}_{4}$ $\mathrm{Z}<0.862$; perusahaan diklasifikasikan "gagal ( $f i$ nancial failure)"

Di mana:

$\mathrm{X}_{1}=$ Rasio modal kerja terhadap total aset.

$\mathrm{X}_{2}=$ Rasio pendapatan sebelum bunga dan pajak terhadap total aset.

$\mathrm{X}_{3}=$ Rasio pendapatan sebelum pajak terhadap total utang lancar.

$\mathrm{X}_{4}=$ Rasio penjualan terhadap total aset. 
Jika nilai S-score $>0,862$ maka perusahaan diprediksi sebagai perusahaan yang berpotensi sehat (tidak berpotensi bangkrut). Sedangkan jika nilai $S$-score $<0,862$ maka perusahaan diprediksi sebagai perusahaan yang berpotensi mengalami kebangkrutan.

\section{d. Zmijewski (1984)}

Perluasan studi dalam prediksi kebangkrutan dilakukan oleh Zmijewski (1983) yang menambah validitas rasio keuangan sebagai alat deteksi kegagalan keuangan perusahaan. Model yang berhasil dikembangkan yaitu:

$X=-4,3-4,5 X_{1}+5,7 X_{2}-0,004 X_{3}$

Rasio keuangan yang dianalisis adalah rasiorasio keuangan yang terdapat pada model zmijewski sebagai berikut.

$\mathrm{X}_{1}=$ (return on asset)

$\mathrm{X}_{2}=$ (debt ratio)

$\mathrm{X}_{3}=$ (current ratio)

Zmijewski (1984) menyatakan bahwa perusahaan dianggap distress jika probabilitasnya lebih besar dari 0. Dengan kata lain, nilai X-nya adalah 0 .

Maka dari itu, nilai cut-off yang berlaku dalam model ini adalah 0 . Hal ini berarti, perusahaan yang nilai X-nya lebih besar dari atau sama dengan 0 diprediksi akan mengalami $f i$ nancial distress di masa depan. Sebaliknya, perusahaan yang nilai X-nya kecil dari 0 diprediksi tidak akan mengalami financial distress.

\section{Pengembangan Hipotesis}

\section{a. Hipotesis Model Altman}

Berdasarkan penelitian yang dilakukan oleh Rahmi Fadhilla (2010) yang menyatakan bahwa model altman dapat diimplementasikan dalam memprediksi terjadinya kesulitan keuangan pada perusahaan dan juga merupakan model prediksi terbaik.

$\mathrm{H}_{1}$ : Model altman dapat memprediksi kondisi financial distress perusahaan sektor industri barang konsumsi di Indonesia

\section{b. Hipotesis Model Grover}

Berdasarkan penelitian yang dilakukan oleh Ni Made E.D.P. dan Maria M.R.S. (2013) yang menyatakan bahwa model grover merupakan model prediksi yang paling sesuai diterapkan pada perusahaan food and beverage yang terdaftar di Bursa Efek Indonesia (BEI).

$\mathrm{H}_{2}$ : Model springate dapat memprediksi kondisi financial distress perusahaan sektor industri barang konsumsi di Indonesia

\section{c. Hipotesis Model Springate}

Berdasarkan penelitian yang dilakukan oleh Muhammad Rifqi (2009) yang menyatakan bahwa model asli yang paling baik adalah model springate dibandingkan model altman, ohlson, dan zmijewski.

$\mathrm{H}_{3}$ : Model springate dapat memprediksi kondisi financial distress perusahaan sektor industri barang konsumsi di Indonesia

\section{d. Hipotesis Model Zmijewski}

Berdasarkan penelitian yang dilakukan oleh Rismawaty (2012) yang menyatakan model zmijewski adalah model yang paling sesuai diterapkan untuk perusahaan di Indonesia karena tingkat keakuratannya paling tinggi dibandingkan model prediksi lainnya.

$\mathrm{H}_{4}$ : Model zmijewski dapat memprediksi kondisi financial distress perusahaan sektor industri barang konsumsi di Indonesia 
Tabel 3.1

Data EPS dan Average EPS Industri yang Tercatat pada BEI Periode Tahun 2011-2016

\begin{tabular}{|c|l|r|r|r|r|r|r|r|}
\hline \multirow{2}{*}{ No. } & \multirow{2}{*}{ INDUSTRI } & \multicolumn{6}{c|}{ EPS Industri } & \multirow{2}{*}{ AVERAGE } \\
\cline { 3 - 8 } & & $\mathbf{2 0 1 1}$ & $\mathbf{2 0 1 2}$ & $\mathbf{2 0 1 3}$ & $\mathbf{2 0 1 4}$ & $\mathbf{2 0 1 5}$ & $\mathbf{2 0 1 6}$ & \\
\hline 1 & Agriculture & 191 & 197 & 83 & 151 & -9 & 102 & 119,17 \\
\hline 2 & Mining & 395 & 263 & 110 & 97 & 48 & 43 & 159,33 \\
\hline 3 & Basic Industry \& Chemicals & 245 & 219 & 91 & 130 & 52 & 116 & 142,17 \\
\hline 4 & Miscellaneous Industry & 863 & -279 & 47 & 118 & 24 & 18 & 131,83 \\
\hline 5 & Consumer Goods Industry & 5705 & 5584 & 5666 & 5823 & 5295 & 6647 & $\mathbf{5 7 8 6 , 6 7}$ \\
\hline 6 & $\begin{array}{l}\text { Property, Real Estate \& } \\
\text { Building Construction }\end{array}$ & 56 & 74 & 111 & 117 & 111 & 109 & 96,33 \\
\hline 7 & Infrastructure, Utilities \& & 87 & 145 & 23 & 70 & 44 & 64 & 72,17 \\
\hline 8 & Fransportations & 111 & 175 & 132 & 114 & 99 & 101 & 122,00 \\
\hline 9 & Trade, Service, \& Investment & 96 & 167 & 132 & 172 & 144 & 73 & 130,67 \\
\hline
\end{tabular}

Sumber: IDX Fact Book 2011-2016

\section{e. Hipotesis Perbandingan Semua Model Pre- diksi Financial Distress}

Pengujian kandungan informasi untuk mengetahui apakah ada perbedaan secara statistik antar-model dan menemukan model prediksi terbaik dalam memprediksi tingkat kesulitan keuangan perusahaan.

$\mathrm{H}_{5}$ : Terdapat satu model dengan tingkat akurasi tertinggi dalam memprediksi kondisi financial distress perusahaan sektor industri barang konsumsi di Indonesia.

\section{METODE PENELITIAN}

\section{Pemilihan Objek Penelitian}

Financial distress adalah kondisi perusahaan mengalami laba bersih operasi (net operation income) negatif selama beberapa tahun dan selama lebih dari satu tahun tidak melakukan pembayaran dividen, pemberhentian tenaga kerja atau menghilangkan pembayaran dividen (Almilia dan Kristijadi, 2003). Financial distress hanyalah salah satu penyebab bangkrutnya perusahaan. Namun tidak berarti semua perusahaan yang mengalami financial distress akan menjadi bangkrut.
Pemilihan objek penelitian didasarkan pada industri penghasil barang-barang konsumsi tercatat dari tahun 2012-2015. Industri ini sebenarnya merupakan sektor industri dengan tingkat average EPS tertinggi selama tahun 2011-2016, namun tercatat hanya 1 perusahaan di sektor ini yang melakukan pembayaran dividen.

\section{Populasi dan Sampel}

Populasi penelitian ini adalah seluruh perusahaan tercatat dalam industri penghasil barangbarang konsumsi di Bursa Efek Indonesia. Model pengambilan sampel yang diterapkan dalam penelitian ini adalah model purposive sampling, yaitu model pemilihan sampel secara tidak acak yang informasinya diperoleh dengan menggunakan pertimbangan tertentu dengan tujuan atau masalah penelitian (Indriantoro 2002:131). Perusahaan yang akan menjadi sampel penelitian ini adalah perusahaan yang memiliki indikasi financial distress yakni selama dua tahun mengalami laba bersih operasi (net operating income) negatif dan lebih dari satu tahun tidak melakukan pembayaran dividen. 
Dari pertimbangan tersebut terpilih 29 perusahaan dari 34 perusahaan terdaftar dalam industri barang-barang konsumsi di BEI yang memiliki laporan keuangan publik hingga tahun 2015. Periode 2012-2015 yang akan dijadikan sampel dalam penelitian ini.

\section{Jenis Data, Sumber Data, dan Teknik Pengumpulan Data}

Jenis data yang digunakan dalam penelitian ini adalah data sekunder yakni data penelitian yang diperoleh peneliti secara tidak langsung melalui media perantara (diperoleh dan dicatat oleh pihak lain). Data tersebut berupa laporan keuangan dari masing-masing perusahaan publik antara tahun 2011 sampai 2016. Di mana sumber data tersebut diperoleh dari Pusat Informasi Pasar Modal (PIPM), buku ICMD dan juga dengan mengakses internet www.jsx.co.id atau www.idx.co.id.

\section{Teknik Analisis Data}

Analisis data dalam penelitian ini melalui tahapan sebagai berikut.

1. Menghitung indeks financial distress dari setiap model prediksi yang digunakan.

2. Mengelompokkan hasil indeks financial distress tersebut berdasarkan hasil kriteria kondisi keuangan perusahaan. Dalam penelitian ini, perusahaan yang masuk ke dalam grey area akan dikategorikan ke dalam perusahaan yang tidak mengalami kondisi financial distress, karena menurut penelitian Suwitno (2013), 93\% perusahaan yang masuk dalam kategori grey area tidak mengalami kebangkrutan pada tahun-tahun operasional berikutnya.
3. Memvalidasi sampel dengan cara mencocokkan hasil perhitungan indeks financial distress tersebut dengan kejadian kondisi keuangan sebenarnya, yang mengacu pada 2 kondisi yakni keadaan net income negative dan tidak adanya dividend payment.

4. Selanjutnya dari hasil validasi sampel tersebut, akan dihitung persentase keakuratan model prediksi.

5. Melakukan uji normalitas

6. Melakukan uji asumsi klasik

7. Melakukan uji hipotesis

5. Definisi Operasional dan Pengukuran Variabel

Dalam penelitian ini terdapat dua variabel penelitian sebagai berikut.

1. Variabel dependen

Variabel dependen dalam penelitian ini adalah financial distress di mana disajikan dalam bentuk variabel dummy dengan ukuran binomial yaitu, 1 untuk perusahaan yang mengalami kesulitan keuangan dan 0 untuk perusahaan yang tidak mengalami kesulitan keuangan. Sedangkan variabel independen dalam penelitian ini adalah model altman, grover score, springate, dan zmijewski.

2. Variabel independen

Variabel independen dalam penelitian ini adalah working capital, current assets, current liabilities, total assets, retained earning, EBIT, market value of equity, total liabilities, sales, net income, dan ROA.

\section{Definisi Operasional dan Pengukuran Varia-} bel

Keseluruhan data yang terkumpul selanjutnya dianalisis untuk dapat memberikan jawaban 
dari masalah yang dibahas dalam penelitian ini. Dalam menganalisis data, peneliti menggunakan program SPSS 23.0 for windows untuk memperkuat hasil perhitungan.

\section{a. Uji Normalitas Data}

Uji Normalitas merupakan prasyarat dalam uji awal penganalisisan data. Uji ini dimaksudkan untuk memperlihatkan bahwa sampel data yang diambil dari populasi merupakan data yang berdistribusi normal atau tidak. Ada beberapa teknik yang dapat digunakan untuk menguji normalitas, antara lain uji kormogorov-smirnov dan uji chi-kuadrat. Karena jumlah sampel hasil financial distress lebih dari 100, hasil merupakan data rasio, data merupakan data tunggal yang belum dikelompokkan, maka pada penelitian ini, uji normalitas yang digunakan adalah uji kormogorov-smirnov. Jika $\mathrm{P}$ value (sig) $>0.05$ menandakan data tersebut berdistribusi normal, sebaliknya bila nilai signifikansi $<0,05$ akan menandakan data tersebut tidak berdistribusi normal.

\section{b. Uji Asumsi Klasik}

\section{1) Uji Multikolinearitas}

Uji ini dilakukan untuk menemukan apakah model regresi yang digunakan memiliki korelasi antar-variabel bebasnya. Karena, model regresi yang baik adalah model regresi yang tidak memiliki korelasi antara variable bebas. Untuk melihat ada atau tidaknya multikolinearitas dalam model regresi dilihat dari nilai tolerance dan lawannya variance inflation factor (VIF).

Batasan yang umum dipakai untuk menunjukkan adanya multikolinearitas adalah nilai tolerance $<0,10$ atau VIF $<10$ (Ghozali, 2005). Jika nilai tolerance $>0,10$ menandakan tidak terjadi keadaan multikolinearitas terhadap data yang diuji. Sebaliknya, bila nilai tolerance $<0,10$ menandakan adanya multikolinearitas.

Selanjutnya, bila nilai VIF $<10,00$ akan dikatakan tidak terjadi multikolinearitas dan bila nilai VIF > 10,00 menandakan terjadinya multikolinearitas.

\section{2) Uji Autokorelasi}

Uji autokorelasi bertujuan untuk menguji apakah dalam model regresi yang diuji ini terdapat residual data pengganggu yang akan memengaruhi nilai data observasi yang berikutnya. Model regresi yang baik adalah model regresi yang bebas dari kejadian autokorelasi.

Uji autokorelasi yang digunakan adalah uji durbin watson (DW test) dengan dasar pengambilan keputusan bila d lebih kecil dari $\mathrm{dL}$ atau lebih besar dari (4-dL) maka Ho ditolak yang artinya terjadi autokorelasi. Jika d terletak di antara dU dan (4-dL), maka Ho diterima yang artinya tidak ada autokorelasi. Sebaliknya, bila nilai d terletak di antara $\mathrm{dL}$ dan $\mathrm{dU}$ atau di antara (4-dU) dan (4-dL) memberikan informasi bahwa data regresi yang digunakan tersebut akan menghasilkan kesimpulan yang tidak pasti.

\section{3) Uji Heteroskedastisitas}

Uji ini dilakukan untuk menguji apakah dalam model regresi yang diuji terjadi ketidaksamaan variance dari residual tiap data observasi. Ketidaksamaan variance dari residual ini dinamakan sebagai keadaan heteroskedastisitas.

Model regresi akan dikatakan baik, bila model regresi tersebut memiliki keadaan yang heteroskedastis. Dasar analisis yang dapat digunakan untuk menentukan heteroskedastisitas adalah sebagai berikut. 
a. Jika nilai signifikansi $>(0.05)$ maka tidak terjadi heteroskedastisitas.

b. Jika nilai signifikansi < $(0.05)$ maka mengindikasikan terjadinya heteroskedastisitas.

\section{c. Pengujian Hipotesis}

\section{1) Uji t}

Uji ini dilakukan untuk mengetahui apakah variabel bebas secara parsial berpengaruh secara signifikan terhadap variabel terikatnya. Uji $t$ dilakukan dengan cara membandingkan nilai $\mathrm{t}$ hitung dengan nilai $t$ tabel pada tingkat signifikan $5 \%(0,05)$.

Jika nilai $\mathrm{t}$ hitung $>\mathrm{t}$ tabel maka variabel bebas berpengaruh terhadap variable terikatnya. Dan sebaliknya bila nilai t hitung < nilai t tabel, mengartikan tidak adanya pengaruh antara variable bebas terhadap variable terikatnya.

1. Jika $\mathrm{t}$ hitung $<\mathrm{t}$ tabel atau $\mathrm{p}$ value $>\mathrm{a}$ dikatakan tidak signifikan, dan hipotesis penelitian ditolak.

2. Jika $\mathrm{t}$ hitung $>\mathrm{t}$ tabel atau $\mathrm{p}$ value $<\mathrm{a}$ dikatakan tidak signifikan, dan hipotesis penelitian diterima.

Dan apabila nilai signifikansi $\mathrm{t}$ hitung variabel bebas < 0,05 menandakan adanya pengaruh secara signifikan terhadap variable terikat, begitu pula sebaliknya bila nilai signifikansi t hitung variable bebas $>0,05$.

\section{2) Uji F}

Uji f digunakan untuk mengetahui pengaruh simultan dari dua variabel independen atau lebih terhadap variabel independennya. Dasar pengambilan keputusan ini didasarkan pada nilai $F$ hitung terhadap nilai $\mathrm{F}$ tabel serta nilai signifikansinya.
Variabel bebas secara simultan memiliki pengaruh terhadap variabel terikatnya apabila nilai $\mathrm{F}$ hitung $>$ nilai $\mathrm{F}$ tabel dan akan dikatakan tidak berpengaruh bila nilai $\mathrm{F}$ hitung $<$ nilai $\mathrm{F}$ tabel. Secara signifikansi, bila nilai signifikansi $<0,05$ menandakan adanya pengaruh antara variabel bebas dengan variabel terikat, sebaliknya bila nilai signifikansi $>0,05$ yang menandakan tidak ada pengaruh sama sekali antara variable bebas dengan variabel terikatnya.

\section{c. Uji Koefisien Determinasi}

Koefisien determinasi (R2) digunakan untuk seberapa besar variasi variabel bebas terhadap naik turunnya variasi nilai variabel terikat. Uji ini menjelaskan kemampuan model regresi terhadap variasi variabel terikatnya.

Nilai koefisien determinasi adalah antara nol sampai dengan satu. Nilai R2 menandakan seberapa besar persentase pengaruh variabel bebas terhadap variabel terikat. Apabila nilai R2 semakin kecil, maka kemampuan variabel independen dalam menjelaskan variasi variabel dependen rendah. Apabila nilai R2 mendekati satu, maka variabel independen memberikan hampir semua informasi yang dibutuhkan untuk memprediksi variasi variabel dependen.

\section{HASIL PENELITIAN DAN PEMBAHAS- AN}

\section{Hasil Penelitian}

Bab ini akan memaparkan hasil penelitian yang telah dilakukan dan dilanjutkan dengan perhitungan statistik serta pengujian hipotesis untuk menjawab identifikasi masalah yang telah dirumuskan. 
Tabel 4.1 Statistik Deskriptif

\begin{tabular}{|l|c|r|r|r|c|}
\hline \multicolumn{1}{|c|}{ Method } & N & \multicolumn{1}{c|}{ Min } & \multicolumn{1}{c|}{ Max } & \multicolumn{1}{c|}{ Mean } & $\begin{array}{c}\text { Std. } \\
\text { Deviation }\end{array}$ \\
\hline Altman Z-Scores & 116 & -0.220 & 4.78 & 1.553 & 1.03007 \\
\hline Grover G-Scores & 116 & -0.270 & 3.55 & 1.338 & 0.87477 \\
\hline Springate S-Scores & 116 & -0.039 & 5.49 & 1.954 & 1.22683 \\
\hline Zmijewski X-Scores & 116 & -4.825 & 3.39 & -2.169 & 1.47167 \\
\hline Financial Distress & 116 & 0 & 1 & 0.888 & 0.31682 \\
\hline
\end{tabular}

Sumber: Hasil olah data sekunder dengan SPSS 23.0

Tabel 4.2 Perbandingan Tingkat Akurasi Model Prediksi Financial Distress

\begin{tabular}{|c|c|c|c|c|c|}
\hline \multirow{2}{*}{ Model Prediksi } & \multirow{2}{*}{$\mathbf{N}$} & \multicolumn{2}{|c|}{$\begin{array}{c}\text { Tingkat Akurasi Riil } \\
\text { Berdasarkan }\end{array}$} & \multirow{2}{*}{$\begin{array}{c}\text { Rata- } \\
\text { Rata } \\
\text { Akurasi }\end{array}$} & \multirow{2}{*}{ Peringkat } \\
\hline & & $\begin{array}{l}\text { Net Income } \\
\text { Negatif }\end{array}$ & $\begin{array}{l}\text { Dividend } \\
\text { Payment }\end{array}$ & & \\
\hline Altman Z-Scores & 116 & $38,79 \%$ & $92,24 \%$ & $65.52 \%$ & 1 \\
\hline Grover G-Scores & 116 & $93,97 \%$ & $9,48 \%$ & $51.72 \%$ & 4 \\
\hline Springate S-Scores & 116 & $89,99 \%$ & $40,52 \%$ & $65.09 \%$ & 2 \\
\hline Zmijewski X-Scores & 116 & $92,24 \%$ & $18,97 \%$ & $55.60 \%$ & 3 \\
\hline
\end{tabular}

Sumber: Hasil olah data sekunder

Dari hasil perbandingan tingkat akurasi model prediksi kondisi finansial distress, dapat disimpulkan bahwa model altman G-score memiliki tingkat akurasi tertinggi dibandingkan dengan model-model yang lain, yakni sebesar 65,52\%. Sebenarnya model altman Z-scores ini memiliki tingkat tertinggi dalam memprediksi keadaan financial distress bila dilihat dari kemampuan perusahaan untuk membagikan devidennya dengan nilai akurasi sebesar 92.24\%. Altman Zscore dapat digunakan oleh para manajer keuangan untuk melakukan "maintain" atas value of the firm-nya yang bermula dari kemampuan perusahaan untuk memperoleh laba dan melihat risiko finansial dari perusahaan. Dari sisi investor, Altman Z-score akan menguntungkan bagi investor dari segi kemampuan perusahaan secara konstan untuk membagi dan membayar deviden, selanjutnya menjadi kebijakan investor untuk memilih saham suatu perusahaan yang mampu memberikan kontinuitas return yang optimal. Sedangkan untuk menghindari kesalahan dalam penilaian risiko dan return atas perusahaan, sebaiknya menghindari penggunaan metode grover G-score karena memiliki tingkat akurasi yang paling rendah, hanya sebesar $9.48 \%$. Namun G-score memiliki tingkat akurasi yang tinggi untuk memprediksi tingkat net income, hal ini dikarenakan net income merupakan variabel independen pembentuk dari G-score.

\section{a. Uji Normalitas Kormogorov-Smirnov}

Pengujian ini untuk mengetahui apakah distribusi sebuah data mengikuti atau mendekati distribusi normal. Data yang baik adalah data yang mempunyai pola seperti distribusi normal, yaitu distribusi data tersebut tidak menceng ke 
kiri atau ke kanan. Adapun hasil uji ini dapat terlihat pada tabel berikut ini.

Tabel 4.3 Hasil Uji Normalitas Data

\begin{tabular}{|l|r|r|r|r|}
\hline \multicolumn{1}{|c|}{ Hasil } & Z-Scores & G-Scores & S-Scores & X-Scores \\
\hline $\begin{array}{l}\text { Kolmogorov- } \\
\text { Smirnov }\end{array}$ & 0.058 & 0.212 & 0.097 & 0.245 \\
\hline Sig (2-tailed) & 0.002 & 0.001 & 0.009 & 0.001 \\
\hline
\end{tabular}

Sumber: Hasil Olah Data Sekunder dengan SPSS 23.0

Suatu data dikatakan berdistribusi normal bila Pvalue (sig.) $>0.05$, dari hasil data di atas dapat disimpulkan bila data sampel yang diuji merupakan data yang berdistribusi normal dan dapat dilakukan pengujian yang berikutnya.

\section{b. Uji Multikolinearitas}

Uji ini berguna untuk memastikan apakah di dalam sebuah model regresi ada interkorelasi atau kolinearitas antar-variabel bebas. Adapun hasil uji ini dapat terlihat pada tabel berikut ini,

Tabel 4.4 Hasil Uji Multikolineraritas Data

\begin{tabular}{|l|r|r|r|r|}
\hline $\begin{array}{c}\text { Collinearity } \\
\text { Status }\end{array}$ & Z-Scores & G-Scores & S-Scores & X-Scores \\
\hline Tolerance & 0.9502 & 0.68 & 0.7433 & 0.8526 \\
\hline VIF & 1.0592 & 1.5917 & 1.3483 & 1.1836 \\
\hline
\end{tabular}

Sumber: Hasil Olah Data Sekunder dengan SPSS 23.0

Dari keseluruhan data dapat diketahui bahwa pada data tidak ada nilai tolerance yang lebih kecil dari 0,1 dan tidak ada data yang memiliki nilai VIF lebih dari 10. Sehingga dapat dikatakan hasil uji multikolinearitas menunjukkan bahwa tidak terjadi korelasi di antara variabel independen di mana semua model memenuhi asumsi multikolinearitas dengan batasan nilai tolerance $<0.10$ dan $\mathrm{VIF}<10$.

\section{c. Uji Autokorelasi}

\begin{tabular}{|l|r|r|r|r|}
\hline \multicolumn{1}{|c|}{ Hasil } & Z-Scores & G-Scores & S-Scores & X-Scores \\
\hline $\begin{array}{l}\text { Durbin } \\
\text { Watson Test }\end{array}$ & 1.989 & 1.953 & 1.933 & 1.967 \\
\hline $\begin{array}{l}\text { Standard } \\
\text { Error }\end{array}$ & 0.005 & 0.005 & 0.005 & 0.005 \\
\hline
\end{tabular}

Tabel 4.5 Hasil Uji Autokorelasi Data

Sumber: Hasil Olah Data Sekunder dengan SPSS 23.0

Pengujian ini dilakukan untuk menguji apakah ada masalah auto korelasi. Pengujian dilakukan melalui uji Durbin Watson. Dengan melihat tabel, batasan nilai DWtest $\mathrm{dU}<\mathrm{d}<(4-\mathrm{dL})$ berada, pada 1.462 sampai 2.22. Untuk itu, diputuskan bahwa model ini telah terbebas dari kemungkinan adanya autokorelasi

\section{d. Uji Heteroskedastisitas}

Tabel 4.6 Hasil Uji Heteroskedastisitas Data

\begin{tabular}{|l|c|c|c|c|c|}
\hline \multirow{2}{*}{ Model } & \multicolumn{2}{|c|}{ Unstandardized } & Stdize & \multirow{2}{*}{ Sig. } \\
\cline { 2 - 4 } & Beta & $\begin{array}{c}\text { Std. } \\
\text { Error }\end{array}$ & Beta & & \\
\hline $\begin{array}{l}\text { Altman } \\
\text { Z-Scores }\end{array}$ & $-2.229 \mathrm{E}-6$ & 0.0001 & -0.041 & -0.424 & 0.672 \\
\hline $\begin{array}{l}\text { Grover } \\
\text { G-Scores }\end{array}$ & $-5.627 \mathrm{E}-6$ & 0.0000 & -0.109 & -1.176 & 0.242 \\
\hline $\begin{array}{l}\text { Springate } \\
\text { S-Scores }\end{array}$ & 0.010 & 0.0110 & 0.085 & 0.916 & 0.362 \\
\hline $\begin{array}{l}\text { Zmijewski } \\
\text { X-Scores }\end{array}$ & $-5.25 \mathrm{E}-5$ & 0.0001 & -0.175 & -1.899 & 0.600 \\
\hline
\end{tabular}

Sumber: Hasil Olah Data Sekunder dengan SPSS 23.0

Pada tabel di atas dapat dilihat uji Glejser untuk pengujian Heteroskedastisitas menunjukkan bahwa nilai signifikansi untuk semua model yang digunakan dalam memprediksi financial distress memiliki nilai sig di atas nilai alpha (5\%). Oleh karena itu, dapat disimpulkan bahwa model regresi dalam penelitian ini bebas dari heteroskedastisitas. 


\section{Hasil Pengujian Hipotesis}

Pengujian hipotesis dalam penelitian ini akan digunakan uji $\mathrm{t}$, pengujian tambahan dilakukan untuk melihat kelayakan model dengan mengamati hasil uji $\mathrm{F}$ dan uji koefisien determinasi (R2) selanjutnya uji binomial sebagai uji tambahan yang akan digunakan sebagai alat perbandingan di antara model kesulitan keuangan yang digunakan. Berikut adalah penjelasan hasil uji analisis data tersebut.

\section{Hipotesis Pertama: model altman dapat mem-} prediksi kondisi financial distress perusahaan sektor industri barang konsumsi di Indonesia

Tabel 4.7 Uji T Model Altman Z-Score

\begin{tabular}{|c|c|c|c|c|c|c|}
\hline \multicolumn{7}{|c|}{ Coefficients $^{a}$} \\
\hline \multirow{2}{*}{\multicolumn{2}{|c|}{ Model }} & \multicolumn{2}{|c|}{$\begin{array}{l}\text { Unstandardized } \\
\text { Coefficients }\end{array}$} & \multirow{2}{*}{$\begin{array}{c}\begin{array}{c}\text { Standardized } \\
\text { Coefficients }\end{array} \\
\text { Beta } \\
\end{array}$} & \multirow[b]{2}{*}{$\mathrm{t}$} & \multirow[b]{2}{*}{ Sig. } \\
\hline & & B & $\begin{array}{l}\text { Std. } \\
\text { Error }\end{array}$ & & & \\
\hline \multirow[t]{2}{*}{1} & (Constant) & 2,852 & ,091 & & 31,372 & $6,6 \mathrm{E}-58$ \\
\hline & $\begin{array}{l}\text { FINANCIAL } \\
\text { DISTRESS }\end{array}$ & $-1,884$ & ,109 &,- 850 & $-17,204$ & $1,8 \mathrm{E}-33$ \\
\hline
\end{tabular}

Tabel 4.8 Uji F Model Altman Z-Score

\begin{tabular}{|c|c|c|c|c|c|c|}
\hline \multicolumn{7}{|c|}{ ANOVA $^{a}$} \\
\hline \multicolumn{2}{|c|}{ Model } & $\begin{array}{c}\text { Sum of } \\
\text { Squares }\end{array}$ & df & $\begin{array}{l}\text { Mean } \\
\text { Square }\end{array}$ & $\mathrm{F}$ & Sig. \\
\hline \multirow[t]{3}{*}{1} & Regression & 88,092 & 1 & 88,092 & 295,994 &, $000^{b}$ \\
\hline & Residual & 33,928 & 114 & ,298 & & \\
\hline & Total & 122,021 & 115 & & & \\
\hline \multicolumn{7}{|c|}{ a. Dependent Variable: ALTMAN Z-SCORE } \\
\hline \multicolumn{7}{|c|}{ b. Predictors: (Constant), FINANCIAL DISTRESS } \\
\hline
\end{tabular}

Dari hasil pengujian financial distress dengan metode altman di atas dapat diketahui bahwa nilai signifikan $\mathrm{t}$ sebesar 1,8E-33 yang mengartikan bahwa nilai (sig.) lebih kecil dari nilai probabilitas 0.05. Maka hasil uji t untuk model altman disimpulkan berpengaruh positif dalam memprediksi kondisi financial distress perusahaan. Nilai signifikansi F sebesar 295,994 dengan level of signifikan lebih kecil dari nilai probabilitasnya sebesar 0,05 menandakan tingginya pengaruh penilaian altman Z-score dalam memprediksi keadaan kesahan keuangan suatu perusahaan, baik itu financial distress maupun good financial.

Selanjutnya bila dilihat dari nilai koefisien determinasi (R-square) di atas, dapat dilihat bahwa nilai pengaruh modelling multiple discriminate analysis altman Z-score cukup tinggi 0.720 atau $72 \%$. Nilai ini menunjukkan persentase kemampuan model altman dalam memberikan signaling kondisi keuangan suatu perusahaan.

Hal ini sejajar dengan nilai signifikansi uji $t$ dan uji $f$ yang berpengaruh positif. Berdasarkan analisis hasil tabel di atas dapat disimpulkan bahwa $\mathrm{H} 1$ bisa diterima. Hasil penelitian ini sejalan dengan penelitian yang dilakukan oleh Mihail Diakomihalis Accounting Department, Technological Educational Institute of Epirus Psathaki, 48100 Preveza, Greece (2012) dalam judul penelitiannya The Accuracy of Altman's Models in Predicting Hotel Bankruptcy yang menyatakan bahwa model altman dapat diimple-

Tabel 4.9 Uji Determinasi (R2) Model Altman Z-Score

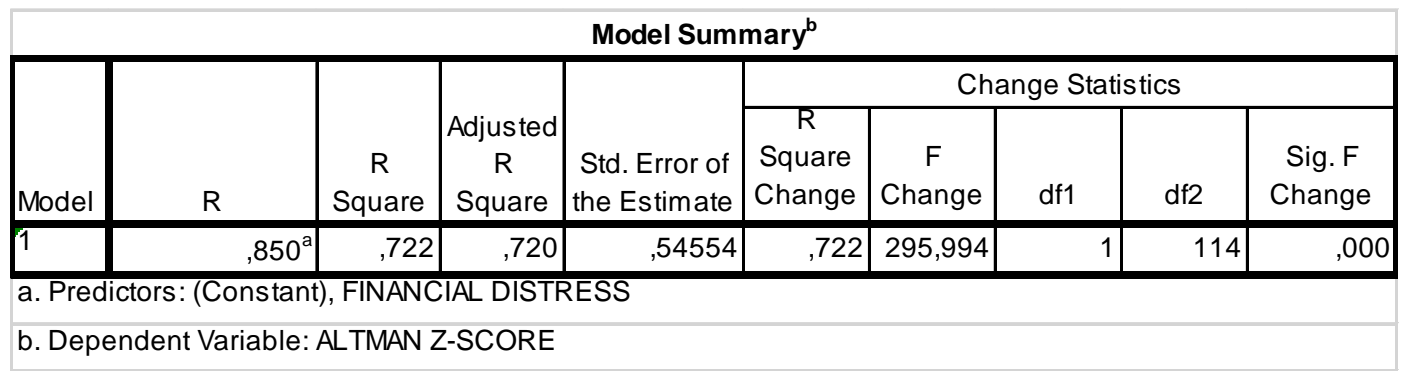


mentasikan dalam memprediksi terjadinya kesulitan keuangan pada perusahaan dan juga merupakan model prediksi terbaik. Di dalam model Altman digunakan beberapa rasio yang telah diuji mampu memprediksi kondisi kesulitan keuangan suatu perusahaan. Di antaranya adalah rasio working capital/total assets yang digunakan untuk mengukur likuiditas dari total aktiva dan posisi modal kerja (neto). Atau merupakan rasio keuangan yang bisa digunakan untuk mengukur likuiditas suatu perusahaan. Di mana rasio likuiditas adalah rasio yang memperlihatkan hubungan kas perusahaan dan aktiva lancar lainnya terhadap kewajiban lancar. Dan rasio-rasio lain yang digunakan dalam model ini juga memiliki kemampuan untuk menguji tingkat stabilitas perusahaan.

\section{Hipotesis Kedua: model grover dapat mem-} prediksi kondisi financial distress perusahaan sektor industri barang konsumsi di Indonesia

Tabel 4.10 Uji T Model Grover G-Score

\begin{tabular}{|c|c|c|c|c|c|c|c|c|c|c|}
\hline \multicolumn{11}{|c|}{ Coefficients $^{a}$} \\
\hline \multirow[b]{2}{*}{ Mode } & & \multicolumn{2}{|c|}{$\begin{array}{l}\text { Unstandardized } \\
\text { Coefficients }\end{array}$} & \multirow{2}{*}{$\begin{array}{c}\begin{array}{c}\text { Standardized } \\
\text { Coefficients }\end{array} \\
\text { Beta }\end{array}$} & \multirow[b]{2}{*}{$\mathrm{t}$} & \multirow[b]{2}{*}{ Sig. } & \multicolumn{2}{|c|}{$\begin{array}{c}95,0 \% \text { Confidence } \\
\text { Interval for B }\end{array}$} & \multicolumn{2}{|c|}{ Collinearity Statistics } \\
\hline & & B & $\begin{array}{l}\text { Std. } \\
\text { Error }\end{array}$ & & & & $\begin{array}{l}\text { Lower } \\
\text { Bound }\end{array}$ & $\begin{array}{l}\text { Upper } \\
\text { Bound }\end{array}$ & Tolerance & VIF \\
\hline 1 & (Constant) & 1,365 & ,080 & & 17,073 & ,000 & 1,207 & 1,523 & & \\
\hline & $\begin{array}{l}\text { KONDISI } \\
\text { FINANCIAL }\end{array}$ & $-1,582$ & ,609 &,- 236 & $-2,598$ & ,011 & $-2,788$ &,- 376 & 1,000 & 1,000 \\
\hline
\end{tabular}

a. Dependent Variable: GROVER G-SCORE

Tabel 4.11 Uji F Model Grover G-Score

\begin{tabular}{|c|c|c|c|c|c|c|}
\hline \multicolumn{7}{|c|}{ ANOVA $^{a}$} \\
\hline \multicolumn{2}{|c|}{ Model } & $\begin{array}{c}\text { Sum of } \\
\text { Squares }\end{array}$ & df & Mean Square & $\mathrm{F}$ & Sig. \\
\hline \multirow[t]{3}{*}{1} & Regression & 4,920 & 1 & 4,920 & 6,751 &, $011^{b}$ \\
\hline & Residual & 83,081 & 114 & ,729 & & \\
\hline & Total & 88,001 & 115 & & & \\
\hline
\end{tabular}

Tabel 4.12 Uji Koefisien Determinasi (R2) Model Grover G-Score

\begin{tabular}{|l|r|r|r|r|}
\multicolumn{5}{|c|}{ Model Summary } \\
\hline \\
Model & $\mathrm{R}$ & $\mathrm{R}$ & $\begin{array}{c}\text { Adjusted } \\
\mathrm{R} \\
\text { Square }\end{array}$ & $\begin{array}{c}\text { Square } \\
\text { Std. Error of the } \\
\text { Estimate }\end{array}$ \\
\hline 1 &, $236^{\mathrm{a}}$ &, 056 &, 048 &, 85368 \\
\hline
\end{tabular}

a. Predictors: (Constant), KONDISI FINANCIAL

b. Dependent Variable: GROVER G-SCORE 
Dari hasil pengujian pada tabel di atas dapat diketahui bahwa metode memprediksikan kondisi kesehatan keuangan suatu perusahaan melalui G-scores Grover ini tidak dapat dilakukan. Ditunjukkan dengan nilai signifikan $t$ sebesar 2.598 lebih besar dari nilai probabilitas 0.05 dan memiliki hubungan yang terbalik dengan kondisi financial distress riil yang terjadi, sekalipun pada uji $\mathrm{F}$ yang memperlihatkan tingkat signifikansi $<0.05$, namun metode ini sangat lemah dalam memberikan signaling financial distress suatu perusahaan. Hal ini ditunjukkan dengan hasil uji koefisien determinasi (R2) model G-score hanya sebesar 0.056 atau sama dengan 5.6\% sehingga hasil uji hipotesis $\mathrm{H} 2$ ditolak.

3. Hipotesis Ketiga: model springate dapat memprediksi kondisi financial distress perusahaan sektor industri barang konsumsi di Indonesia

Tabel 4.13 Uji T Model Springate S-Score

Coefficients $^{a}$

\begin{tabular}{|c|c|c|c|c|c|c|}
\hline \multirow{2}{*}{\multicolumn{2}{|c|}{ Model }} & \multicolumn{2}{|c|}{$\begin{array}{c}\text { Unstandardized } \\
\text { Coefficients }\end{array}$} & \multirow{2}{*}{$\begin{array}{c}\begin{array}{c}\text { Standardized } \\
\text { Coefficients }\end{array} \\
\text { Beta }\end{array}$} & \multirow[b]{2}{*}{$\mathrm{t}$} & \multirow[b]{2}{*}{ Sig. } \\
\hline & & B & Std. Error & & & \\
\hline \multirow[t]{2}{*}{1} & (Constant) & 2,280 & ,104 & & 21,917 & 1,09892E-42 \\
\hline & $\begin{array}{l}\text { FINANCIAL } \\
\text { DISTRESS }\end{array}$ & $-1,802$ & ,245 &,- 568 & $-7,370$ & 2,91595E-11 \\
\hline
\end{tabular}

a. Dependent Variable: SPRINGATE SCORE

Tabel 4.14 Uji F Model Springate S -Score

ANOVA $^{a}$

\begin{tabular}{|l|l|r|r|r|r|r|}
\hline Model & & $\begin{array}{r}\text { Sum of } \\
\text { Squares }\end{array}$ & df & Mean Square & F & Sig. \\
\hline 1 & Regression & 55,857 & 1 & 55,857 & 54,318 &, $000^{\mathrm{b}}$ \\
& Residual & 117,231 & 114 & 1,028 & & \\
\cline { 2 - 4 } & Total & 173,089 & 115 & & & \\
\hline
\end{tabular}

a. Dependent Variable: SPRINGATE SCORE

b. Predictors: (Constant), FINANCIAL DISTRESS

Tabel 4.15 Uji Koefisien Determinasi (R2) Model Springate S -Score

\begin{tabular}{|c|c|c|c|c|}
\hline \multicolumn{5}{|c|}{ Model Summary } \\
\hline Model & $\mathrm{R}$ & R Square & $\begin{array}{l}\text { Adjusted } \\
\text { R Square }\end{array}$ & $\begin{array}{l}\text { Std. Error of } \\
\text { the Estimate }\end{array}$ \\
\hline 1 & & ,323 & ,317 & 1,014074024 \\
\hline
\end{tabular}

a. Predictors: (Constant), FINANCIAL DISTRESS

b. Dependent Variable: SPRINGATE SCORE 
Berdasarkan analisis hasil tabel di atas dapat disimpulkan bahwa H3 bisa diterima, dilihat dari nilai signifikansi uji $\mathrm{T}<0.05$, nilai uji $\mathrm{F}$ dengan signifikansi kesalahan $<0.05$ dan hasil uji determinasi yang mengisyaratkan bahwa kemampuan springate dalam financial distress hanya sebesar 32.3\%. Sekalipun nilai uji T dan $F$ yang berada pada nilai signifikansi yang lebih kecil dari 0,05 yang bias mengartikan diterimanya $\mathrm{H} 3$, tapi dengan kemampuan signaling model springate yang lebih kecil dari 50\% ini mengartikan bahwa S-score tidak mampu memberikan kontribusi bagi manajer keuangan sebagai alat analisis dalam memberikan signaling.

4. Hipotesis Keempat: model zmijewski dapat memprediksi kondisi financial distress perusahaan sektor industri barang konsumsi di Indonesia

Tabel 4.16 Uji T Model Zmijewski X-Score

\begin{tabular}{|c|c|c|c|c|c|c|}
\hline \multicolumn{7}{|c|}{ Coefficients $^{a}$} \\
\hline \multirow{2}{*}{\multicolumn{2}{|c|}{ Model }} & \multicolumn{2}{|c|}{$\begin{array}{c}\text { Unstandardized } \\
\text { Coefficients }\end{array}$} & \multirow{2}{*}{$\begin{array}{c}\begin{array}{c}\text { Standardized } \\
\text { Coefficients }\end{array} \\
\text { Beta }\end{array}$} & \multirow[b]{2}{*}{$\mathrm{t}$} & \multirow[b]{2}{*}{ Sig. } \\
\hline & & B & Std. Error & & & \\
\hline \multirow[t]{2}{*}{1} & (Constant) & $-2,451$ & ,101 & & $-24,314$ & $6,3 \mathrm{E}-47$ \\
\hline & $\begin{array}{l}\text { FINANCIAL } \\
\text { DISTRESS }\end{array}$ & 4,080 & ,384 & ,705 & 10,629 & $9,4 \mathrm{E}-19$ \\
\hline
\end{tabular}

Tabel 4.17 Uji F Model Zmijewski X -Score

\begin{tabular}{|c|c|c|c|c|c|c|}
\hline \multicolumn{7}{|c|}{ ANOVA $^{a}$} \\
\hline \multicolumn{2}{|c|}{ Model } & $\begin{array}{c}\text { Sum of } \\
\text { Squares }\end{array}$ & $d f$ & Mean Square & $\mathrm{F}$ & Sig. \\
\hline \multirow[t]{3}{*}{1} & Regression & 123,970 & 1 & 123,970 & 112,969 &, $000^{b}$ \\
\hline & Residual & 125,102 & 114 & 1,097 & & \\
\hline & Total & 249,071 & 115 & & & \\
\hline
\end{tabular}

Tabel 4.18 Uji Koefisien Determinasi (R2) Model Zmijewski X -Score

\begin{tabular}{|c|c|c|c|c|}
\hline \multicolumn{5}{|c|}{ Model Summary ${ }^{b}$} \\
\hline Model & $\mathrm{R}$ & R Square & $\begin{array}{l}\text { Adjusted } \\
\text { R Square }\end{array}$ & $\begin{array}{l}\text { Std. Error of } \\
\text { the Estimate }\end{array}$ \\
\hline 1 &, $705^{a}$ & ,498 & ,493 - r & 1,04755996 \\
\hline
\end{tabular}


Dari hasil pengujian pada tabel di atas dapat diketahui bahwa nilai signifikan t sebesar 9.4E-19, menandakan bahwa nilai Uji $\mathrm{T}$ lebih kecil dari nilai probabilitas 0.05 maka hasil uji $\mathrm{t}$ untuk model zmijewski disimpulkan berpengaruh positif dalam memprediksi kondisi financial distress perusahaan. Selanjutnya untuk Uji $F$ dengan nilai 112.969 dan tingkat signifikansi $<0.05$ yang berarti hasil signifikansi ini lebih kecil dari nilai probabilitasnya sebesar 0.05 , memberikan arti bahwa hasil perhitungan model zmijewski dapat digunakan untuk memprediksi ataupun memberikan signaling kondisi financial distress perusahaan. Kemampuan model zmijewski adalah sebesar 49,8\% dalam memberikan sinyal financial distress suatu perusahaan.

Hasil tersebut menyimpulkan bahwa $\mathrm{H} 4$ bisa diterima. Dengan demikian, model zmijewski dapat memprediksi kondisi financial distress perusahaan. Hasil penelitian ini sejalan dengan penelitian yang dilakukan oleh Rismawaty (2012) yang menyatakan model zmijewski adalah model yang paling sesuai diterapkan untuk perusahaan di Indonesia karena tingkat keakuratannya paling tinggi dibandingkan model prediksi lainnya. Dalam model zmijewski terdapat rasio-rasio yang telah teruji keakuratannya dalam memprediksi tingkat financial distress perusahaan. Rasio tersebut antara lain: return on asset, debt ratio, dan current ratio. Di mana return on assets ratio ini digunakan untuk mengukur kemampuan manajemen dan efisiensi penggunaan aset perusahaan dalam menghasilkan keuntungan. Rasio yang tinggi menunjukkan efisiensi manajemen. Sebaliknya, rasio yang rendah maka semakin rendah ukuran efektivitas terhadap keseluruhan operasional perusahaan. Debt ratio merupakan rasio yang mengukur tingkat persentase aktiva perusahaan yang dibiayai oleh utang. Leverage yang diukur dengan debt ratio dapat digunakan untuk memprediksi potensi terjadinya financial distress pada perusahaan. Semakin tinggi nilai debt ratio perusahaan, maka probabilitas perusahaan akan dalam kondisi financial distress semakin besar pula current ratio.

5. Hipotesis Kelima: terdapat satu model dengan tingkat akurasi tertinggi dalam memprediksi kondisi financial distress perusahaan sektor industri barang konsumsi di Indonesia

Hasil olah data regresi perbandingan masing-masing model yang digunakan dalam memprediksi kondisi financial distress perusahaan dapat dilihat pada tabel regresi setiap model yang telah dijelaskan di atas. Semua tabel tersebut menunjukkan nilai koefisien determinasi dan nilai signifikansi $F$ setiap model yang diperbandingkan. Hasil menyatakan bahwa model altman Z-score memiliki nilai koefisien determinasi tertinggi sebesar $72.2 \%$ dan nilai signifikansi F sebesar 295.994 yang menyatakan bahwa model altman Z-scores merupakan model yang memiliki tingkat akurasi paling tinggi dibandingkan model lain dalam memprediksi kondisi financial distress perusahaan-perusahaan yang termasuk dalam industri barang-barang konsumsi yang terdaftar di Bursa Efek Indonesia.

Selanjutnya, model zmijewski X-scores menjadi model kedua dengan tingkat akurasi tertinggi dalam memprediksi kondisi financial distress perusahaan dengan nilai koefisien determinasi sebesar 49,8\% dan nilai signifikansi $\mathrm{F}$ sebesar 112,969 .

Perbedaan antara hasil analisis model altman, model grover, model springate, dan model zmijewski dalam memberikan signaling kondisi financial distress perusahaan-perusahaan dalam industri barang-barang konsumsi di BEI pada 
periode 2012-2015, disebabkan karena adanya perbedaan dalam menggunakan perhitungan yang digunakan pada model-model tersebut altman. Berdasarkan penjelasan di atas, berikut adalah model prediksi financial distress yang telah diurutkan berdasarkan persentase nilai terbaik atau nilai tertinggi.

Tabel 4.19 Peringkat Uji Determinasi Model Financial Distress

\begin{tabular}{|c|l|c|}
\hline Peringkat & \multicolumn{1}{|c|}{$\begin{array}{c}\text { Model Prediksi } \\
\text { Financial Distress }\end{array}$} & Nilai R2 \\
\hline 1 & Altman Z-Scores & 0.722 \\
\hline 2 & Zmijewski X-Scores & 0.498 \\
\hline 3 & Springate S-Scores & 0.323 \\
\hline 4 & Grover G-Scores & 0.056 \\
\hline
\end{tabular}

Sumber: Hasil Olah Data dengan SPSS 23.0

Satu hal yang perlu diingat dari hasil penelitian ini, bahwa seluruh model financial distress ini sebenarnya merupakan signaling factor untuk kondisi keuangan perusahaan, bukan hanya untuk melihat financial distress saja tapi juga akan memberikan kontribusi positif dalam penilaian kebijakan seorang manajer keuangan dalam memprediksikan operational distress atau likuidasi. Selain itu, setiap model yang diciptakan tidak pernah sempurna. Maka dari itu, hasil prediksi ini tidak boleh dianggap sebagai hasil absolut. Hasil prediksi hanya sebatas indikator supaya investor atau kreditor lebih berhati-hati atas perusahaan yang diprediksi mengalami financial distress dan mencari informasi tambahan mengenai perusahaan bersangkutan.

\section{E. KESIMPULAN DAN SARAN}

\section{Kesimpulan}

Berdasarkan hasil yang diperoleh dari analisis data, maka dapat ditarik kesimpulan sebagai berikut.
1) Model altman dapat digunakan untuk memprediksi kesulitan keuangan perusahaan.

2) Model grover tidak dapat digunakan untuk memprediksi kesulitan keuangan perusahaan.

3) Model springate dapat digunakan untuk memprediksi kesulitan keuangan perusahaan.

4) Model zmijewski dapat digunakan untuk memprediksi kesulitan keuangan perusahaan.

5) Perbandingan model analisis yang paling efektif dan akurat dalam memberikan signal kondisi financial distress perusahaan-perusahaan dalam industri barang-barang konsumsi yang paling efektif dan akurat dalam memprediksi dan memberikan signal info kondisi finansial adalah model altman Z-scores. Tingkat kesesuaian prediksi yang dihasilkan model altman Z-scores berdasarkan pada hasil uji hipotesis di mana nilai koefisien determinasi dan nilai signifikansi F model altman Z-scores merupakan nilai tertinggi dibandingkan model lain yang digunakan untuk memberikan signaling terjadinya financial distress.

\section{Keterbatasan}

Keterbatasan dalam penelitian ini umumnya bersifat non-teknis, salah satunya proses input data dan perhitungan yang cukup banyak meningkatkan peluang terjadinya human error. Upaya untuk meminimalkan kesalahan ini dilakukan melalui pembandingan antara data yang telah di-input dengan data yang ada pada ICMD. Keterbatasan lainnya merupakan keterbatasan waktu yang digunakan dalam proses penulisan penelitian ini.

\section{Saran}

1) Penelitian ini hanya sebatas membandingkan akurasi antar-model prediksi, bukan menciptakan model prediksi yang baru. 
2) Jumlah sampel dan periode terbatas hanya dari tahun 2012-2015.

3) Agar lebih valid lagi, sebaiknya pada penelitian selanjutnya, jumlah sampel dan periode sebaiknya ditambah lagi.

4) Penelitian selanjutnya dapat menggunakan model-model prediksi lain yang ada.

\section{F. DAFTAR RUJUKAN}

Adnan, H. dan Arisudhana, D. 2010. Analisis Kebangkrutan Model Altman Z-Score Dan Springate Pada Perusahaan Industri Property. Jurnal. Jakarta: Universitas Budi Luhur.

Adriana. 2011. Analisis Prediksi Kebangkrutan Menggunakan Metode Springate pada Perusahaan Foods and Beverages yang Terdaftar di Bursa Efek Indonesia Periode 2006-2010. Jurnal. Universitas Riau.

Adriani. 2009. Analisis Perbandingan Efektivitas Model Prediksi Keberlangsungan Usaha Antara Model Analisa Altman, Springate dan Zmijewski. Jurnal.

Almilia, Luciana Spica dan Kristijadi. 2003. "Analisis Rasio Keuangan untuk Memprediksi Kondisi Financial Distress Perusahaan Food and Beverages yang terdaftar di BEJ." Jurnal Akuntansi dan Auditing Indonesia, Vol. 7, No. 2, Desember.

Budiharto, Stefanus Benny. 2013. Perbandingan Ketepatan Model-Model Prediksi Kebangkrutan untuk Memprediksi Penerbitan Opini Audit Going Concern (Studi pada Perusahaan Manufaktur yang Terdaftar di BEI). Skripsi. Yogyakarta: Universitas Atma Jaya Yogyakarta.

Bayu, Stevanus Aditya. 2014. Perbandingan Model Prediksi Kebangkrutan Perusahaan Publik (Model Altman, Springate, dan
Ohlson). Tesis. Yogyakarta: Universitas Atma Jaya Yogyakarta.

Christianti, Ari. 2013. Akurasi Prediksi Financial Distress: Perbandingan Model Altman dan Model Ohlson. Jurnal. Bali: Universitas Udayana.

Fadhila, Rahmi. 2010. Analisis Kondisi Financial Distress dan Pengaruhnya Terhadap Harga Saham pada Perusahaan Sektor Aneka Industri di BEI. Skripsi. Padang: Universitas Andalas.

Fatmawati, mila (2012). Penggunaan the Zmijewski Model, The Altman Model, dan The Springate Model sebagai Prediktor Delisting. Jurnal Keuangan dan Perbankan, Vol. 16, No. 1, Januari 2012, hlm. 56-65.

Ghozali, Imam. 2006. Aplikasi Analisis Multivariate dengan Program SPSS, Edisi Empat. Semarang: Badan Penerbit Universitas Diponegoro.

Hadi, Syamsul dan Anggraeni, A. 2008. Pemilihan Prediktor Delisting Terbaik (Perbandingan antara The Zmijewski Model, The Altman Model, dan The Springate Model). Jurnal. Universitas Islam Indonesia.

Indriantoro, Nur. dan B. Supomo. 2002. Metodologi Penelitian Bisnis. Yogyakarta: BPFE.

Mihail Diakomihalis Accounting Department, Technological Educational Institute of Epirus Psathaki, 48100 Preveza, Greece. 2012. The Accuracy of Altman's Models in Predicting Hotel Bankruptcy.

Peter dan Yoseph. 2011. Analisis Kebangkrutan dengan Metode Z-Score Altman, Springate dan Zmijewski pada PT Indofood Sukses Makkur Tbk Periode 2005-2009. Jurnal Ilmiah Akuntansi, Nomor 04 Tahun ke-2 Januari-April 2011.

Rifqi, Muhammad. 2009. Analisis Perbandingan Model Prediksi Financial Distress Altman, 
Ohlson, Zmijewski dan Springate dalam Penerapannya di Indonesia. Skripsi. Jakarta: Universitas Indonesia.

Rismawaty. 2012. Analisis Perbandingan Model Prediksi Financial Distress Altman, Springate, Ohlson, dan Zmijewski (Studi Empiris Pada Perusahaan Food and Beverages yang Terdaftar di Bursa Efek Indonesia). Skripsi. Makassar: Universitas Hasanuddin.

Safitra B., Kertahadi dan Handayani. 2012. Analisis Metode Altman (Z-Score) sebagai
Alat Evaluasi Guna Memprediksi Kebangkrutan Perusahaan (Studi Pada Industri Rokok yang Terdaftar di Bei Periode 20072011). Jurnal. Malang: Fakultas Ilmu Administrasi Universitas Brawijaya.

Suwitno, Lanny. 2013. Perbandingan Ketepatan Bankruptcy Prediction Models untuk Memprediksi Financial Distress dan Kepailitan pada Perusahaan Manufaktur yang Terdaftar di Bursa Efek Indonesia. Skripsi. Yogyakarta: Universitas Atma Jaya. 